Indexed by

\title{
Scopus
}

\section{APPROACHES TO DEVELOPING A STRATEGIC PROGRAM FOR HIGH-TECH ENTERPRISE IN THE CONTEXT OF DIGITAL TRANSFORMATION}

Crossref

KOBSON

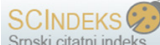

gil Google

\section{Sergey V. Novikov}

Moscow Aviation Institute

(National Research University), Moscow,

Russian Federation

\author{
Andrey A. Sazonov \\ Moscow Aviation Institute \\ (National Research University), \\ Moscow, \\ Russian Federation
}

Key words: technological concept "Industry 4.0", digital transformation of high-tech enterprise, development of business processes, digital production modeling doi:10.5937/jaes0-31875

Cite article:

V. Novikov S., A. Sazonov A. (2022) APPROACHES TO DEVELOPING A STRATEGIC PROGRAM FOR HIGH-TECH ENTERPRISE IN THE CONTEXT OF DIGITAL TRANSFORMATION, Journal of Applied Engineering Science, 20(1), 41 - 52, DOI:10.5937/ jaes0-31875

Online aceess of full paper is available at: www.engineeringscience.rs/browse-issues 


\title{
APPROACHES TO DEVELOPING A STRATEGIC PROGRAM FOR HIGH-TECH ENTERPRISE IN THE CONTEXT OF DIGITAL TRANSFORMATION
}

\author{
Sergey V. Novikov*, Andrey A. Sazonov \\ Moscow Aviation Institute (National Research University), Moscow, Russian Federation
}

The article is devoted to the consideration of approaches to the development of a strategic program for the development of high-tech enterprise in the context of digital transformation in order to increase the level of digital maturity of the enterprise. The digital maturity levels of the operating model are considered, followed by an example of a possible distribution of the spectrum of technologies according to these digital maturity levels. The article discusses issues related to the mechanism for implementing digital transformation at industrial enterprises in modern conditions. The article considers the categorical apparatus affecting the management of digital changes: digital transformation, as applied to industry. In addition, the authors highlight the main problem points to which the management of enterprises should pay attention when implementing digital transformation and draw conclusions regarding changes in approaches to organizing the system of interaction within the company. Analytical and expert assessments of project development forecasts using modern digital technologies are used as research methods. The study is based on a comprehensive analysis and subsequent assessment of the main results of the implementation of the processes of technological transformation of projects in industry, followed by the definition of its key areas and directions. In project management in the era of digital transformation, the most applicable approach is one that combines tight control of results on the horizon of strategic planning and inspiring flexibility in organizing work over short distances.

Key words: technological concept "Industry 4.0", digital transformation of high-tech enterprise, development of business processes, digital production modeling

\section{INTRODUCTION}

The concept of "Industry 4.0" and digitalization has received a fairly wide range of distribution in the world and in Russia. A holistic understanding of the technologies that make up this concept has already developed, ways of their effective application have been identified, and the concept is already considered as a tool necessary for transforming a certain set of elements from the composition of various business models [1].

Since the beginning of the industrialization of society, the paradigms of industrial development have changed under the condition of technological breakthroughs, which later became known as industrial revolutions (IR). Three IRs have passed in succession:

- high mechanization of production processes;

- transition to the use of electricity in production;

- digitalization of the processes of manufacturing enterprises.

Industry 4.0 involves the transformation of key aspects of manufacturing. Consulting company BCG identifies nine key technologies that are aimed at forming the fourth IR: autonomous robotization, simulation modeling, horizontal and vertical integration of systems, augmented reality, IoT, cloud technologies, additive manufacturing, cybersecurity and large. The introduction of Industry 4.0 technologies will allow factories to reduce production costs by $10-30 \%$, logistics costs by $10-30 \%$ and quality management costs by $10-20 \%$ [2]. Industry 4.0 technologies are designed to reduce time-to-market, improve custom- er engagement, economies of scale and more efficient use of resources. The development of modern innovative technologies contributes to the transformation of entire industries and individual types of business. Leading experts and experts in digitalization have developed a "high-level" transformation roadmap for high-tech enterprises, which includes a series of sequential steps. This map can also be successfully used by small and medium-sized enterprises that have chosen for themselves a priority strategy of incremental improvements [3]. The first step is to determine the current position and state of the enterprise, its strategic position from the point of view of internal and external perspectives. The second step allows the desired target state to be determined, taking into account the promising technology research taken into account. Step three is the direct implementation of the transition process through the development of special prototypes and design of the business model. The fourth step is the development of a detailed plan that includes an analysis of the scaling processes and organization of change management to organize the transition of the entire enterprise to the target state. However, the digitalization process requires significant investments, so enterprises that have chosen this path of development need to correctly prioritize tactical and long-term goals, draw up a roadmap and assess the future economic effect of the introduction of these technologies. This article aims to conduct research on practice-oriented approach- 
es to the formation of a competent and effective digital transformation program. The results of the study were the development of models for the digital maturity of an enterprise and a detailed structural description of two main practical approaches to developing a program for organizing digital transformation [4].

\section{THEORETICAL BASIS}

Digital transformation is the complex integration of process innovation into the structure of an enterprise. Process innovation refers to the introduction of advanced or significantly modernized methods of organizing production or delivery, i.e. this type of innovation implies qualitative changes not only in equipment and technology, but also in the software used at the enterprise. The particular difficulty of introducing process innovations is associated, as a rule, with their systemic nature: changes that have occurred in one part of the production system of an enterprise will unconditionally affect other subsystems and processes [5]. The integration of any complex technological innovations can lead to situations where unforeseen technological problems may appear, need to master fundamentally new skills, growth of requirements and level of qualifications of the working staff and the likelihood that there will be significant changes in the working production processes throughout production line. It is necessary to take into account the additional difficulties associated with the integration of advanced technologies and the lack of an unambiguous understanding of all the nuances associated with their implementation, i.e. the scope of future changes is unclear. The difficulties discussed above make technological innovations, especially when viewed in the context of digital transformation, a very difficult task that requires timely and high-quality optimization of processes and actions that may go beyond the initially defined scope of work associated with their implementation [6]. The authors of the article carried out a detailed analysis of the activities of large high-tech enterprises, on the basis of which the following provisions were systematized that are faced by enterprises actively introducing digital factories, for convenience they were divided, dividing them into three broad categories:

- Enterprise staff. Employees of the enterprise often experience a lack of time required for a common understanding and vision of the whole unified concept of creating a digital factory and the mechanisms for its implementation. As a rule, employees differently perceived and shifted the volume of changes that occurred and the need to develop their own production skills. Additional difficulties arise in terms of the existing attachment to the previous generation of production technologies and the emerging threat to the already established competencies, i.e. factors of a negative attitude to future changes appear [7]

- Manufacturing technologies. Rather high indicator of uncertainty and complexity in the development of digital technologies undoubtedly complicates the process of assessing potential production and eco- nomic effects, therefore, an ambiguous business rationale for the need for their implementation is created [8]. Indeed, the concept of a digital factory is inherent in the systemic nature of implementation, which creates a certain uncertainty about a number of specific changes that may be required in other related technologies, production, technological and organizational processes, as well as the skills of working employees. The overestimated cost of implementing the digital factory concept, especially in the early years, only exacerbates the uncertainty, since the benefits from the investment will be possible only for an indefinite period of time [5].

- Processes. High-tech enterprises are experiencing some difficulty in changing traditional procedures and different groups of processes in the implementation of digital transformation. In factories often there is a lack a systematic methodological approach to the integration of modern innovative design models, which allow obtaining more adaptive and flexible results, as well as significantly optimizing the time required to enter the market. Typically, production processes are implemented almost identically over a long period of time and become an integral part of everyday practice. This highly structured culture is nearly impossible to change [9]. Modern innovative models aimed at business transformation are necessary in these contexts to ensure the transformation process and to create conditions for attracting specialists with high competencies to support it.

\section{Economic transformations associated with the implementation of projects for the development and implementation of Industry 4.0 technologies}

A key driver of Industry 4.0 technologies is the increased integration of "cyber-physical systems" or CPS, into manufacturing processes. Possible economic transformations associated with the implementation of projects for the development and implementation of Industry 4.0 technologies include the following possible changes in the field of production:

1. Increasing labor productivity by reducing the number of personnel, the emergence of new technologies that can increase the efficiency of services provided and products;

2. Emergence of new types of industrial technologies and new industrial production, caused by:

- development of mobile Internet and cloud technologies;

- development of 3D printing;

- emergence of new materials, genetic and biotechnologies, which will give a new impetus to the development of medicine, agriculture, pharmaceuticals, plastics and polymers and biofuels;

3. Widespread use of innovative solutions, a new level of automation and robotization of production processes, an increase in the computing power of computers and the use of the capabilities of large 
amounts of data, artificial intelligence and machine learning, which make it possible to automate operations that were previously perceived as impossible for machines to perform;

4. Development of remote access and control over production equipment with the development of loT, i.e. the ability to control physical objects using the Internet;

5. Emergence of new sources of energy and energy technologies, increasing the energy efficiency of production;

6. Blurring the boundaries between industries and activities. At the same time, changes are also forecasted in the sphere of consumption, including:

- development of the sharing economy;

- increasing interest in ecological products;

- growing importance for consumers of ethical aspects of consumption and problems of personal data protection;

- development of new specific products, services and business models due to an aging population and an increase in life expectancy.

The rise of workplace automation in many of its forms can dramatically increase productivity and increase employee productivity. Automation technology can help take the burden of repetitive administrative work and keep employees focused on solving more complex problems, while reducing the risk of human error by allowing them to focus on value-added tasks [10]. Examples of already well-established and almost invisible automation tools that did not exist 25 years ago are programming and modeling software used by architects, engineers and designers, robotic medical instruments used by doctors and surgeons and search engine technologies that allow researchers to find more relevant information. Theoretically, these technologies remove tasks from workers, but in practice their overall effect is to significantly enhance and increase their abilities [11]. With the introduction of Industry 4.0 technologies, the picture will change, namely, the role of machines and the algorithm in solving specific problems will at least double. The increase in the share of machines in solving production problems will be especially noticeable in such functions as "reasoning and decision making", "administration" and "finding and obtaining the necessary information". Most of the tasks of organizing and processing information, searching and transferring information will be performed using automation technologies [12].

For the successful implementation of all components of the digital transformation program, the management of enterprises must act as "technological agents" of change and clearly understand and evaluate the digital strategy of the enterprise. It must necessarily cover the entire enterprise as a whole and take into account the rejection of the disparate work of divisions with the subsequent integration of key staff, resources, technologies and processes [13]. Within the framework of three subject areas discussed above (enterprise staff, production technologies and processes), the authors managed to success- fully carry out systematization based on the allocation of maturity levels when organizing the process of transition to a digital factory, as well as to classify the key activity indicators that underlie the organization of the entire digital space [14]. The model was modified in accordance with the results of research and opinion of experts. The final model is shown in the Table 1.

\section{RESEARCH PART}

We will conduct a study of an approach to the formation of a program aimed at carrying out digital transformation of an enterprise based on replicating existing tools. Duplication of tools assumes that the enterprise has available various pilot innovative technologies that demonstrate positive results and are characterized by a certain degree of versatility, i.e. these technologies can be successfully applied in most similar enterprise processes [15]. The practical application of this approach is largely based on a well-designed maturity model in which the levels were originally designed. An example of preparing an enterprise maturity model in terms of its use of certain technologies that can be used in replication processes is shown in the Table 2.

The composition of technologies at each individual maturity level should be selected separately for each specific enterprise or function [16]. The development of a program of initiatives to organize digital transformation based on the use of technology replication tools can include the following stages in its structural composition [17]:

Stage 0 "Creation of special register of digital tools and filling with data of the maturity assessment model".

Tasks:

- to analyze digital tools that are already used at the enterprise and offered by specialists as the best world practices and also select only relevant tools from those offered by suppliers on the market;

- to describe potential effects expected from the instruments;

- to describe necessary technical conditions for the integration of these tools;

- to distribute tools at main levels of maturity model in such a way that the effect of their use is maximized.

Results:

- to obtain register for all digital instruments;

- to develop full-fledged digital maturity model for specific enterprise.

Stage 1. Diagnostics of current level of maturity indicators of the enterprise in the structural context of production / lines.

Tasks:

- to determine current list of instruments and degree to which they correspond to each maturity level;

- to determine criteria for effectiveness of integration of instruments;

- to conduct inventory of all implemented digital tools; 
Table 1: Content structure of digital maturity levels of the operating model

\begin{tabular}{|c|c|c|c|}
\hline Maturity level & Ongoing processes & Technologies used & Staff \\
\hline 1 & 2 & 3 & 4 \\
\hline \multicolumn{4}{|c|}{ Level №5 «Adaptability» } \\
\hline \multirow{2}{*}{$\begin{array}{l}\text { Systems required to provide } \\
\text { a set of corrective actions } \\
\text { for all types of installed pro- } \\
\text { duction equipment, operat- } \\
\text { ing independently or within } \\
\text { the framework of existing } \\
\text { corporate system in order } \\
\text { to maximize efficiency, have } \\
\text { been successfully integrated }\end{array}$} & $\begin{array}{c}\text { Development of processes } \\
\text { for the organization of au- } \\
\text { tonomous decision-making } \\
\text { process by systems } \\
\end{array}$ & $\begin{array}{l}\text { Interaction with external } \\
\text { data marts of buyers and } \\
\text { suppliers }\end{array}$ & $\begin{array}{l}\text { Development of practices } \\
\text { aimed at continuous im- } \\
\text { provement and innovation }\end{array}$ \\
\hline & $\begin{array}{c}\text { Development of processes } \\
\text { for the organization of con- } \\
\text { tinuous forecasting and } \\
\text { planning of future produc- } \\
\text { tion development }\end{array}$ & $\begin{array}{l}\text { Application of artificial } \\
\text { intelligence systems }\end{array}$ & $\begin{array}{l}\text { Inclusion in the structure of } \\
\text { the enterprise of specialists re- } \\
\text { sponsible for the development } \\
\text { of the direction of predictive } \\
\text { analytics and adaptability }\end{array}$ \\
\hline \multicolumn{4}{|c|}{ Level №4 «Predictiveness» } \\
\hline \multirow[t]{2}{*}{$\begin{array}{l}\text { Predictive systems have } \\
\text { been introduced, which } \\
\text { are necessary for compe- } \\
\text { tent and effective fore- } \\
\text { casting of future state, for } \\
\text { example, SAP Analytics } \\
\text { Cloud or Logi Predict }\end{array}$} & $\begin{array}{l}\text { Development of processes } \\
\text { for the analysis of past } \\
\text { and current data and the } \\
\text { use of information ob- } \\
\text { tained from the analysis in } \\
\text { order to carry out various } \\
\text { optimization measures is } \\
\text { underway }\end{array}$ & $\begin{array}{l}\text { Integration in real time of } \\
\text { special systems necessary } \\
\text { for the analysis of cur- } \\
\text { rent activities, which can } \\
\text { independently and auto- } \\
\text { matically carry out various } \\
\text { analytics and generate } \\
\text { warnings and various } \\
\text { kinds of recommendations }\end{array}$ & $\begin{array}{l}\text { Organization of work of } \\
\text { cross-functional sessions, } \\
\text { including also sessions on } \\
\text { data exchange in order to } \\
\text { optimize work on the most } \\
\text { important problems and } \\
\text { opportunities for carrying } \\
\text { out optimization technolo- } \\
\text { gies based on new data } \\
\end{array}$ \\
\hline & $\begin{array}{c}\text { Introduction of special pro- } \\
\text { cedures necessary for orga- } \\
\text { nizing the process of regular } \\
\text { optimization of initiatives }\end{array}$ & $\begin{array}{l}\text { Use of digital twin technology } \\
\text { to organize the testing, optimi- } \\
\text { zation and prototyping process }\end{array}$ & $\begin{array}{c}\text { Attracting additional spe- } \\
\text { cialists (data analysts) to } \\
\text { work }\end{array}$ \\
\hline \multicolumn{4}{|c|}{ Level №3 «Transparency» } \\
\hline \multirow{3}{*}{$\begin{array}{l}\text { Highlighting the most } \\
\text { significant process indica- } \\
\text { tors for visualizing them on } \\
\text { special dashboards with } \\
\text { the ability to track their } \\
\text { changes in real time }\end{array}$} & $\begin{array}{l}\text { Streamlining processes in } \\
\text { data flow management }\end{array}$ & $\begin{array}{l}\text { Improving data accuracy and } \\
\text { analyticity, reducing the amount } \\
\text { of unnecessary information }\end{array}$ & $\begin{array}{l}\text { Organization of training for } \\
\text { employees to work with special } \\
\text { data systems and new devices }\end{array}$ \\
\hline & \begin{tabular}{|c|} 
Development of special pro- \\
cesses that allow for the ac- \\
tive exchange of knowledge \\
and various data between all \\
participants in the process \\
\end{tabular} & $\begin{array}{l}\text { Implementation of innova- } \\
\text { tions in the field of mining } \\
\text { systems for data processing } \\
\text { and analysis }\end{array}$ & $\begin{array}{l}\text { Developing employees' } \\
\text { digital skills }\end{array}$ \\
\hline & $\begin{array}{c}\text { Creation of a unique } \\
\text { cross-functional network } \\
\text { for efficient data exchange }\end{array}$ & $\begin{array}{l}\text { Implementation of special } \\
\text { systems that facilitate data } \\
\text { exchange, for example, inte- } \\
\text { gration of BI systems into the } \\
\text { structure of an enterprise that } \\
\text { allows visualizing data sources }\end{array}$ & $\begin{array}{c}\text { Culture development in } \\
\text { terms of knowledge man- } \\
\text { agement }\end{array}$ \\
\hline \multicolumn{4}{|c|}{ Level №2 «System connection» } \\
\hline \multirow{2}{*}{$\begin{array}{l}\text { Data from the operational } \\
\text { process enter the system } \\
\text { automatically, i.e. without } \\
\text { any specialist participation. } \\
\text { Integration of related sys- } \\
\text { tems has been completed } \\
\text { in full. Control action takes } \\
\text { place remotely }\end{array}$} & $\begin{array}{c}\text { Streamlining a number of } \\
\text { processes in the field of } \\
\text { digital factory integration } \\
\text { (systematic and detailed } \\
\text { description) }\end{array}$ & $\begin{array}{l}\text { Detailed study of all key } \\
\text { areas for the inclusion of } \\
\text { existing systems and tech- } \\
\text { nologies at the enterprise } \\
\text { with future components } \\
\text { included in the digital plant }\end{array}$ & $\begin{array}{l}\text { Development of a culture } \\
\text { of inclusiveness, active } \\
\text { involvement of the com- } \\
\text { pany's employees in the } \\
\text { process of developing a } \\
\text { target vision }\end{array}$ \\
\hline & $\begin{array}{l}\text { Development of processes } \\
\text { aimed at attracting partic- } \\
\text { ipants and stakeholders } \\
\text { external to the enterprise in } \\
\text { order to ensure the "con- } \\
\text { nection" of all systems }\end{array}$ & $\begin{array}{c}\text { Development of a single } \\
\text { independent information } \\
\text { space and data streams, } \\
\text { connection of various } \\
\text { systems }\end{array}$ & $\begin{array}{l}\text { Separation of roles and re- } \\
\text { sponsibilities. The beginning } \\
\text { of the process of attracting } \\
\text { specialists / experts in the } \\
\text { field of business, IT and } \\
\text { high-tech production }\end{array}$ \\
\hline
\end{tabular}




\begin{tabular}{|c|c|c|c|}
\hline Maturity level & Ongoing processes & Technologies used & Staff \\
\hline 1 & 2 & 3 & 4 \\
\hline \multicolumn{4}{|c|}{ Level №1 «Computerization» } \\
\hline \multirow{2}{*}{$\begin{array}{l}\text { Development of automa- } \\
\text { tion processes for any IT } \\
\text { system. Entering into the } \\
\text { database is done manually }\end{array}$} & $\begin{array}{l}\text { Complete elimination of } \\
\text { paper forms and media }\end{array}$ & $\begin{array}{l}\text { Integration of basic systems } \\
\text { in order to organize a com- } \\
\text { petent process for managing } \\
\text { production and the enterprise }\end{array}$ & \multirow{2}{*}{$\begin{array}{l}\text { Employees must take } \\
\text { refresher courses in order to } \\
\text { acquire skills in working with } \\
\text { systems that are in their } \\
\text { area of staff responsibility }\end{array}$} \\
\hline & $\begin{array}{l}\text { Organization of the process } \\
\text { of executing processes only } \\
\text { through system interfaces. Data } \\
\text { transfer in automatic mode }\end{array}$ & $\begin{array}{c}\text { Putting into operation of } \\
\text { the enterprise systems for } \\
\text { automatic transmission of } \\
\text { various data }\end{array}$ & \\
\hline \multicolumn{4}{|c|}{ Level №0 «Basic infrastructure» } \\
\hline $\begin{array}{l}\text { Use of technologies that } \\
\text { do not give significant } \\
\text { business effects in them- } \\
\text { selves, but have a high } \\
\text { degree of importance } \\
\text { when introducing more } \\
\text { advanced technologies }\end{array}$ & $\begin{array}{l}\text { No matter how significant the } \\
\text { impact on the processes is }\end{array}$ & $\begin{array}{l}\text { Creation of a special } \\
\text { infrastructure allowing the } \\
\text { implementation of the fol- } \\
\text { lowing technologies at the } \\
\text { enterprise: industrial WiFi, } \\
\text { as well as local networks }\end{array}$ & $\begin{array}{l}\text { Employees do not need ad- } \\
\text { ditional digital competencies } \\
\text { to work }\end{array}$ \\
\hline
\end{tabular}

Table 2: Example of conditional distribution of enterprise technologies according to main levels of digital maturity

\begin{tabular}{|c|c|c|}
\hline Technological maturity level & $\begin{array}{c}\text { Digital technologies applied in pro- } \\
\text { duction }\end{array}$ & $\begin{array}{l}\text { Using digital technologies in mainte- } \\
\text { nance and repairs }\end{array}$ \\
\hline 1 & 2 & 3 \\
\hline \multirow[b]{2}{*}{ Level №1 «Computerization» } & $\begin{array}{c}\text { Using a group of software and hardware } \\
\text { solutions to automate the control process } \\
\text { of all technological equipment installed } \\
\text { at the enterprise (automated process } \\
\text { control system) }\end{array}$ & $\begin{array}{l}\text { Automated control system for mainte- } \\
\text { nance and repair }\end{array}$ \\
\hline & $\begin{array}{c}\text { Implementation of multi-component man- } \\
\text { ufacturing execution systems }\end{array}$ & $\begin{array}{l}\text { Reliability management system will al- } \\
\text { low reducing the costs of manufacturing } \\
\text { and maintenance of products, as well as } \\
\text { increasing the degree of product reliabil- } \\
\text { ity with a minimum increase in costs for } \\
\text { the necessary activities }\end{array}$ \\
\hline \multirow{3}{*}{ Level №2 «Connectivity» } & $\begin{array}{l}\text { Internet of Things (loT) with certified } \\
\text { crypto protection }\end{array}$ & $\begin{array}{l}\text { Remote assistant specialist based on } \\
\text { augmented reality technologies }\end{array}$ \\
\hline & Industry robotization & \multirow[b]{2}{*}{ Photogrammetry and laser scanning } \\
\hline & $\begin{array}{l}\text { Automation of the process of manual } \\
\text { switching of equipment }\end{array}$ & \\
\hline \multirow{4}{*}{ Level №3 «Transparency» } & \begin{tabular}{|c|} 
Centralized remote control of all production \\
processes in the enterprise without exception
\end{tabular} & $\begin{array}{l}\text { Remote monitoring of equipment health } \\
\text { indicators }\end{array}$ \\
\hline & $\begin{array}{c}\text { Creation of a remote workplace using } \\
\text { tablet computers }\end{array}$ & $\begin{array}{c}\text { Engineering data management system } \\
\text { (EDMS) }\end{array}$ \\
\hline & $\begin{array}{c}\text { ASKUE (automated system for commer- } \\
\text { cial metering of electricity) }\end{array}$ & Technical vision \\
\hline & $\begin{array}{l}\text { Digital dashboards for visual manage- } \\
\text { ment of performance indicators }\end{array}$ & $\begin{array}{c}\text { Remote monitoring of equipment status } \\
\text { and supplier }\end{array}$ \\
\hline \multirow{3}{*}{ Level №4 «Predictiveness» } & Model advisors & Predictive surveillance and maintenance system \\
\hline & Kinetic models & Trust management center \\
\hline & Virtual analyzers & \\
\hline \multirow{2}{*}{ Level №5 «Adaptability» } & \begin{tabular}{|c|}
$\begin{array}{c}\text { Global systems for dynamic optimization } \\
\text { of technological processes }\end{array}$ \\
\end{tabular} & \multirow{2}{*}{$\begin{array}{c}\text { Automatic predictive generation of } \\
\text { special work orders for repair work } \\
\text { based on data obtained from predictive } \\
\text { diagnostics }\end{array}$} \\
\hline & $\begin{array}{c}\text { Automation of the process of entering } \\
\text { spare equipment }\end{array}$ & \\
\hline
\end{tabular}


- to compare implemented digital tools with maturity levels of enterprise;

- to assess the degree of success / completeness of the implementation of digital tools according to the criteria prepared in advance and agreed with the managers of the enterprise;

- to assess the current level of maturity of all objects of enterprise according to a single template.

Results:

- current level of digital maturity of the enterprise has been determined;

- degree of success of integration of existing digital initiatives at the enterprise was determined;

- "heat map" was drawn up of the success of implementation of existing digital tools according to the main criteria.

Stage 2. Development of a map of the transition to the target technological level of maturity of the enterprise in the context of the operation of production lines.

Tasks:

- to determine target level of maturity of all production facilities;

- to start forming target portfolio of instruments in order to organize the transition to the target level by using the structure of register of instruments;

- to determine necessary set of prerequisites necessary for integration of tools selected by specialists;

- to create roadmap for implementation of digital tools.

Results:

- full-fledged roadmap for consistent implementation of digital tools over the course of 3 - 5 years is formed;

- $\quad$ image of the predicted results after the implementation of the roadmap is expressed in the target level of maturity.
It should be noted that the objects for digital transformation are various groups of processes at individual installations or industrial sites of an enterprise, since they can be simultaneously at different levels of maturity and, as a result, strive to different levels of maturity [18]. As a result, after completing all the stages discussed above, an effective digital transformation program should be formed [19], which is focused on replicating various digital tools, which at the preliminary stage have already proven their effectiveness in the framework of pilot projects or directly developed at the enterprise [20].

We consider the process approach and the possibility of its application to form a digital transformation program. This approach assumes that an in-depth analysis of all existing business processes in the enterprise will be carried out in order to identify areas for optimization [21]. The digital transformation process involves the use of advanced innovative technologies as a basic optimization tool. A key feature of using this approach when drawing up a roadmap for digitalization is the need for a detailed analysis of all processes without exception, including even individual manual operations. Detailed specifications of the levels and methods of their practical application are given in the Table 3 .

Digital transformation presupposes full-scale integration of modern information systems, which means that the key object of analysis when developing a roadmap for digital transformation of an enterprise is Level 5. Competent compilation of a profile portfolio of initiatives for the implementation of digital transformation based on the application of the process approach should include the following stages [22]:

Stage №0. Conducting detailed diagnostics of all processes within the boundaries of the digital transformation.

Tasks:

Table 3: Representation of process control levels

\begin{tabular}{|c|c|}
\hline Level in the process model & Application \\
\hline 1 & 2 \\
\hline Level №1. Defines a group of investigated processes & \multirow{3}{*}{$\begin{array}{l}\text { Levels } 1 \text { - } 3 \text { allow determining the existing boundaries } \\
\text { of the enterprise's business, determining its functional } \\
\text { composition, process model, as well as the degree of } \\
\text { interrelation of processes, with the possibility of select- } \\
\text { ing the most key ones from among them }\end{array}$} \\
\hline $\begin{array}{c}\text { Level №2. Develops various business scenarios that } \\
\text { can be used as input in Level } 3 \text { in structural process- } \\
\text { es. As a result, a chain of sequentially interconnected } \\
\text { processes is formed }\end{array}$ & \\
\hline $\begin{array}{c}\text { Level №3. Decomposition of processes to the level of } \\
\text { detailed presentation of business processes }\end{array}$ & \\
\hline $\begin{array}{l}\text { Level №4. Contains models that allow describing steps } \\
\text { in a sequential manner. In this case, a step is a specif- } \\
\text { ic action that a group of users performs, for example, } \\
\text { creating documents, generating application, etc. }\end{array}$ & \multirow{2}{*}{$\begin{array}{l}\text { Detailed detailing of processes to Levels } 4 \text { - } 5 \text { is often } \\
\text { used to develop a specific technical task for integrating } \\
\text { systems, writing standard operating procedures and } \\
\text { user manuals when working in a particular system }\end{array}$} \\
\hline $\begin{array}{l}\text { Level №5. Explains business processes in detail down } \\
\text { to the transaction level. A transaction in this case is a } \\
\text { simple operation, for example, opening an electronic } \\
\text { form or entering any data into a specific electronic field, } \\
\text { etc. }\end{array}$ & \\
\hline
\end{tabular}


- to conduct interviews with the management of the enterprise;

- to analyze end-to-end business processes;

- to assess the timing with the subsequent analysis of the structure of labor costs for certain types of processes;

- to calculate indicators of the cost of processes and total labor costs;

- to conduct an analysis of IT components and IT architecture, information flows, including the study of plans for IT development;

- $\quad$ to conduct external and internal benchmarking.

Results:

- detailed description of all business processes was received;

- $\quad$ indicators of the process execution are given;

- potentially problematic processes in the structure of the enterprise were identified;

- $\quad$ architecture of information systems in detail from the point of view of diagnosed processes, amount of manual work carried out by users in systems, etc. was analyzed.

\section{Stage №1. Development of hypotheses.}

Tasks:

- $\quad$ to assess the current indicators of the cost of processes;

- to analyze the indicators of operational efficiency of current business processes at the enterprise (AS-IS);

- to perform benchmarking of business processes operating at the enterprise;

- to determine the most priority directions and hypotheses for optimization with the aim of their further development.

Results:

- analysis of the current model for the implementation of business processes was carried out for compliance with the best international practices and companies of the reference group;

- $\quad$ preliminary report was drawn up on the comparative analysis of the indicators of the number of staff of the enterprise and the effectiveness of the functions they perform in comparison with similar enterprises operating in the industry of the Russian Federation and in the world;

- detailed description of the models of the considered groups of business processes was obtained with reference to information systems, performed in strict accordance with the selected methodology for modeling business processes;

- results of physical measurements, interview protocols, benchmarking of normative indicators, KPIs of processes and other data were obtained, which confirm the hypotheses put forward in the field of optimization;

- description of various hypotheses was obtained for the organization of further elaboration and testing them at the Stage 2.

Stage №2. Elaboration of hypotheses and development of future initiatives.
Tasks:

- development of special targeted top-level business processes (TO-BE);

- definition of high-level functional provisions and requirements for IT systems.

Results:

- high-level detailed description of business processes with the addition of special information systems (TO-BE);

- list of top-level functional requirements for the main proposed changes in the field of automation was formed;

- management of the enterprise is presented with a list of various initiatives for optimization in the environment of business processes, taking into account their correct arrangement in terms of timelines and predicted results from the conducted high-level assessment of the desired effect of the implementation of the proposed initiatives on the enterprise;

- high-level assessment of business cases was carried out.

\section{Stage №3. Formation of portfolio of projects in the} field of initiatives.

Tasks:

- development of detailed target business processes (TO-BE);

- definition of functional requirements, as well as a number of non-functional requirements for the considered IT systems;

- development of a detailed business case;

- development of projects in the field of optimization;

- development of a specialized program aimed at improving performance indicators.

Results:

- description of the model of business processes was obtained with the reference to information systems, on the basis of full compliance with the selected methodology for modeling business processes (TO-BE);

- sets of various recommendations with a detailed description of changes are grouped into projects, including setting tasks for automation with subsequent assessment of effects, for example, standards and $\mathrm{KPI}$ processes (TO-BE);

- approval was made, quantitative indicators of business cases were calculated for each individual project;

- formed a program aimed at improving operational efficiency, including a plan for its direct implementation;

- formed a communications program for integrating the program into the structure of the enterprise.

The result of the sequential implementation of these stages is a full-fledged program for the digital transformation of the enterprise, aimed at increasing the efficiency indicators and digitalization of the most complex, labor-intensive and problematic processes at the enterprise [23].

\section{RESULTS}

The introduction of Industry 4.0 technologies should pro- 
Table 4: Comparative analysis of various approaches to developing a digital transformation program

\begin{tabular}{|c|c|}
\hline Advantages & Disadvantages \\
\hline \multicolumn{2}{|c|}{ Replication of instruments at the disposal of the enterprise } \\
\hline $\begin{array}{l}\text { Fast start of the program for digital transformation of } \\
\text { production and technological assets }\end{array}$ & $\begin{array}{l}\text { There is a possibility of missing out on benefits due to } \\
\text { insufficient immersion }\end{array}$ \\
\hline $\begin{array}{l}\text { Intensive use and development of existing digital tools } \\
\text { at the enterprise }\end{array}$ & $\begin{array}{l}\text { High level of quality requirements for existing tools and } \\
\text { a team of specialists for their implementation }\end{array}$ \\
\hline $\begin{array}{l}\text { Full transparency and understandability of predicted } \\
\text { results due to the use of a lower degree of uncertainty }\end{array}$ & $\begin{array}{l}\text { Perhaps not a solution to a number of problems, be- } \\
\text { cause this approach cannot solve them effectively }\end{array}$ \\
\hline \multicolumn{2}{|c|}{ Process approach to implementing a digital transformation program for an enterprise } \\
\hline Detailed study of a huge list of a wide variety of processes & $\begin{array}{l}\text { High indicators of labor intensity of the stages, espe- } \\
\text { cially the stage of the diagnostic examination }\end{array}$ \\
\hline Focusing only on real-life problems in the enterprise & $\begin{array}{l}\text { There are high requirements for the qualification level } \\
\text { of methodologists who conduct research and use vari- } \\
\text { ous methods. }\end{array}$ \\
\hline $\begin{array}{c}\text { Potentially high effect in the case of finding processes } \\
\text { that require significant labor intensity and which can } \\
\text { then be successfully automated }\end{array}$ & $\begin{array}{c}\text { Diagnostic stage requires significant attention from the } \\
\text { employees of the enterprise }\end{array}$ \\
\hline $\begin{array}{l}\text { Possibility of conducting an audit with the subsequent } \\
\text { updating of the process model }\end{array}$ & \multirow{2}{*}{$\begin{array}{l}\text { Start of digital transformation is postponed until the } \\
\text { diagnosis is complete }\end{array}$} \\
\hline $\begin{array}{l}\text { Presence of side effects that can be expressed in the } \\
\text { detection of various types of organizational problems }\end{array}$ & \\
\hline
\end{tabular}

vide: reduction in repair costs, reduction in the time for collecting and analyzing data, reduction in the number of defects, reduction in emergency stops and the number of repairs and increase in the useful life of equipment and components. However, any change must be justified and have specific goals. Otherwise, the risk of introducing ineffective improvements, which are accompanied by the emergence of additional costs, increases significantly. Since modern production is based on technologies, a short list of key technologies has been formed that ensure the implementation of the Industry 4.0 concept in practice, and directions for their use are given. The driver of the transformation of production is the desire to improve the efficiency and effectiveness of the enterprise, which is demonstrated by the relation "application of technology - effect in production - impact on financial results". The approaches considered in the article differ significantly from each other. The process of replicating the tools at the disposal of the enterprise considers already existing, planned or proposed digital tools as a "starting point"; it is a top-down approach. The process of developing digital technologies is implemented for the competent solution of specific problems, which means that positive effects will be obtained in any case. Nevertheless, when using this approach to digital transformation, specific problems can be overlooked, the solution of which through the use of advanced digital tools can have a positive effect, but it is absent for them, which means that it must be developed from scratch.

The process approach to the development of a digital transformation program for an enterprise assumes a consistent progressive movement "from the bottom up", i.e. the whole existing set of problems that need to be solved should be considered as a "starting point". This approach can be called more fundamental than the replication process, because to identify existing problems, it is required to do a huge amount of work related to the diagnosis of all processes in the enterprise down to the level of individual operations carried out in manual mode. This circumstance is a significant disadvantage of using this approach, since the beginning of the stratum of digital transformation processes is significantly postponed, which can be started only after the procedure for summing up the results of the diagnostic examination (Table 4 ). It should be noted that the approaches are not mutually exclusive. First, when applying the first approach, before starting the development and replication process, in any case, it is imperative that a complete diagnostic examination procedure be carried out, followed by filling the register of digital instruments with information, but it can also be a separate procedure. Secondly, both considered approaches can be successfully used simultaneously; in parallel with the process of introducing digital tools "from top to bottom", the study of existing problems of the processes and the search for effective solutions "from the bottom up" can be conducted, but only on condition that these approaches have a high degree of synchronization with each other.

Russian enterprises that already have direct experience in implementing digital technologies are creating special centers of excellence in those functional blocks where the pilot project has already been implemented. Often these are operational business units or unique IT unit that tests advanced technologies. The set of various ser- 
vices provided by a specialized competence center may differ, it depends on which model was chosen. To date, there are several models of competence centers that have already developed in Russian enterprises.

Methodological unit. Dedicated center of excellence, existing as a methodology unit, ensures the development of universal standards and methodologies, oversees the architecture and manages data. The development of technological solutions and their subsequent implementation remains in special business functions, in which it is planned to use them in the future.

General corporate center. It is a unique centralized production unit, whose task is to provide a full cycle of work related to the development of a methodological approach and technologies for the implementation of selected solutions. Business functions only shape strategy development initiatives and project requests.

Thus, the article considered a model of the levels of digital maturity of an enterprise, approaches to developing a digital transformation program and, in particular, mechanisms of their use. The information presented in this article can be the basis for the development and adoption of management decisions in practice when implementing the concept of digital transformation.

\section{DISCUSSION}

According to the data obtained after the study by the Organization for Economic Cooperation and Development, there are two key factors that affect the speed of implementation of advanced digital technologies in Russia. The first factor is certain internal capabilities of the enterprise, which include staff management, availability of resources necessary for production, their correct distribution, etc. The second factor that stimulates digital transformation processes includes not only indicators of the current level of competition in the industry, availabil- ity of advanced technologies and capital, but also takes into account trends in the development of legislation. Experts have found that there is a direct relation between the development of human capital in an enterprise and the degree of effectiveness of the implementation of innovative digital technologies. Therefore, the successful implementation of digital initiatives requires the presence of strong leadership skills, as well as the use of modern management practices [24].

The analytical company Digital Leader, together with the companies PricewaterhouseCoopers, International Data Corporation and JSC CROC incorporated conducted a study to determine the technologies that can have the greatest impact on the labor market and business by 2030 . The main obstacles to the full-fledged digital transformation of Russian enterprises are shown in the Figure 1.

The main barriers to the implementation of digital transformation at the moment, according to leading specialists and experts, are infrastructure, financial and process. For the foreseeable future (approximately 3-5 years), inflexible or excessively slow processes will continue to actively hinder the development of digital transformation processes. Lack of investment and regulatory hurdles are predicted to slow down the transition to innovation [1].

The effective combination of advanced technologies and business processes within the enterprises requires employees to have basic IT skills, programs that allow them to maintain and develop these skills, as well as to fully match the nature of work with the competencies that employees of the enterprise have. The leaders of many large Russian enterprises note that the key indicator of readiness for the full implementation of large-scale digital transformation programs is a targeted increase in the digital literacy of working employees. This is especially important for those employees who do not work in IT, but in business units. The scale of future changes that will occur in the business of Russian enterprises due to the impact of innovative

\section{Regulatory barrier}

Communication: lack of close ties between IT department and business unit

Staff shortage of specialists with necessary qualifications

Administrative and managerial: no person in the company responsible for digitalization / no leadership

Financial: no budget for digitalization projects

Infrastructure: outdated infrastructure and lack of integration of new and existing technologies

Process: inflexible or slow

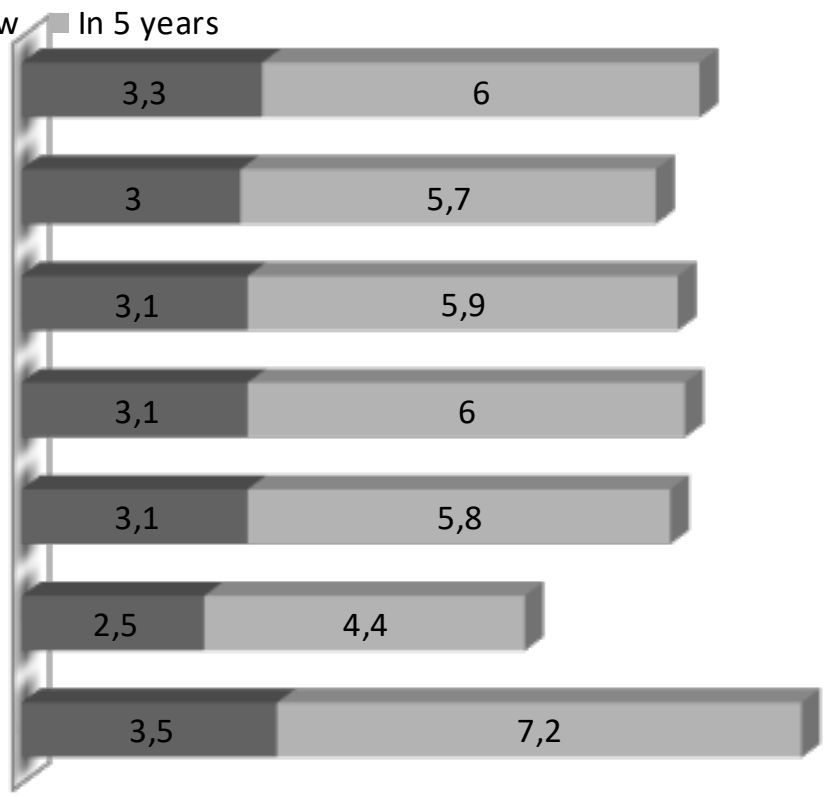

Figure 1: Key barriers to digital transformation 


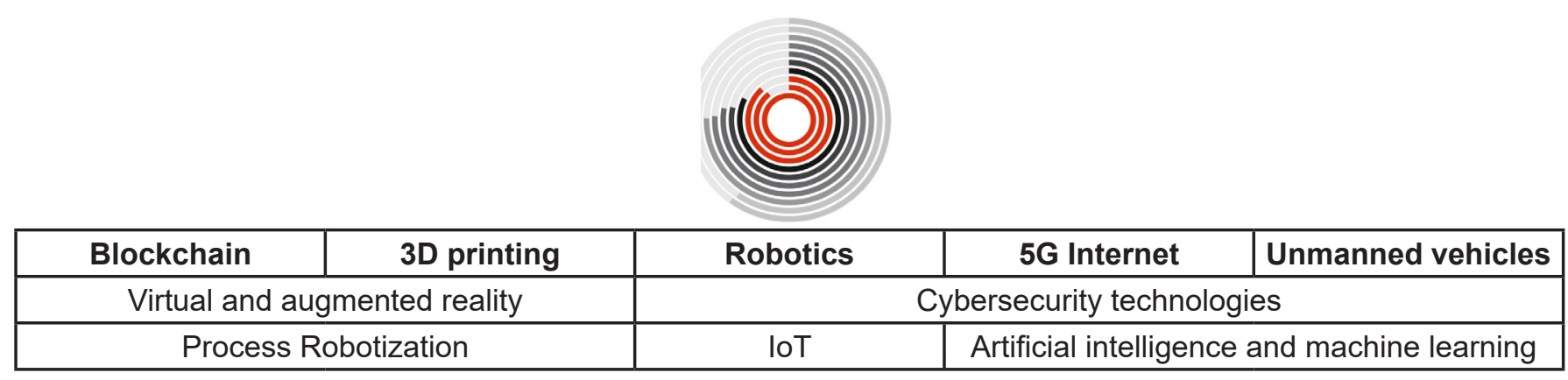

Figure 2: Scale of business change by innovative technologies

technologies on them is shown in the Figure 2.

According to the results of the study, artificial intelligence and machine learning technologies, loT and Process Robotization will fundamentally change activities in Russian enterprises over the next 10 years, according to a number of experts. Under the influence of new technologies, the functions / departments of Russian enterprises will also be transformed [3]:

- IT;

- marketing;

- user / customer support;

- accounting / finance.

The process of transition from the traditional technological approach to the new cost-oriented approach is necessary to improve the quality indicators of the enterprise. Traditionally, within the technological approach, most enterprises are guided by the following approach with an emphasis on innovative technologies [8]:

- selection of advanced breakthrough technologies;

- search, study and subsequent piloting of technologies;

- identification of potential business value.

The value-based approach is aimed at implementing the concept of digital transformation based on the use of the methodology "from a business problem" and includes:

- setting business objectives;

- search, study and analysis of various alternative ways of creating value;

- selection of innovative technologies.

Experts and representatives of the business community believe that the most competent and at the same time effective approach to the implementation of the concept of digital transformation is the use of the methodology "from business tasks" by the enterprise management. This means that an enterprise actively begins to introduce innovative technologies, based on the principle of what result the enterprise management seeks to achieve, what sources of value creation exist, and only then it proceeds to the process of choosing a specific technology for their subsequent implementation [25]. The results of numerous studies show that fundamental approaches to the selection of digitalization projects can be borrowed from the leaders of the Russian market, who are already following the path of implementing various programs aimed at transformation. The focus is on outcome and cost, not technology. When choosing projects, market leaders act in conditions of limited resources, and therefore prioritize processes, and highlight only those areas that will significantly increase the value of the business. The path to successful implementation of transformation, of course, depends on a balanced, strategically sound and thoughtful approach aimed at implementing digital initiatives, which are primarily focused on increasing business value [26].

\section{CONCLUSIONS}

Based on the analysis of the institutional aspects of the digital transformation of industry and factors affecting the formation of an institutional environment conducive to the large-scale introduction of technical and technological means of global megatrends and the development of digital ecosystems, it can be concluded that the following trends exist: world community accepts the challenges of the fourth IR and the search for strategic solutions through the creation of regulatory program documents that would regulate the development of digital transformation of the industry. The United States has adopted the Advanced Manufacturing Partnership program, with an investment fund of over $\$ 500$ million. It is aimed at ensuring the country's competitive advantages through the development of the manufacturing industry. The program envisages cooperation of scientific societies, industrial enterprises and government, organization of joint investment, development of innovations and their commercialization, unification of government, education, science and industry in the network "National Network for Manufacturing Innovation". Among the participants are leading American universities, experimental research institutes and United States industrial holdings. The fund is $\$ 8.5$ billion and is aimed at the development of chemical, biological, energy, robotic industrial sectors, energy conservation and training of specialists with appropriate qualifications.

The modern scientific and technological development policy of the Republic of Korea was formalized in the document "Long-term forecast for the development of science and technology until 2025" ("Long-term Vision for Science and Technology Development toward 2025"), which was adopted in 2013. In 2015, the third strategy for the development of science and technology "Manufacturing Innovation 3.0 Strategy" became the next stage in the 
implementation of the "creative economy". Science and Technology Basic Plan has been approved by the government. The strategic direction was the development of completely new industrial sectors for the economy of the Republic of Korea: big data, 5G telecommunications, artificial intelligence, loT, self-driving cars, virtual reality, intelligent robots, energy conservation, etc. Key ministries in charge of strategic directions for the development of the creative economy, became: Ministry of Science, Telecommunications and Forecasting (Ministry of Science, ICT and Future Planning) and the Ministry of Trade, Industry and Energy (Ministry of Trade, Industry and Energy), which in 2015 mastered more than $60 \%$ of government spending on R\&D (31.9\% and $30.4 \%$, respectively). The investment fund for financing government programs is United States $\$ 7.5$ billion. In new industrial sectors, it is planned to create more than 550000 additional jobs by 2025 .

In Japan, in 2014, a strategy for the development of information and communication technologies "SmartJapanStrategy" was developed. Within its framework, in 2015, the Fifth Basic Plan for Scientific and Technological Development ("Fifth Science and Technology Plan") was adopted, which sets the tasks for the formation of a superintelligent society (SuperSmartSociety 5.0) and plans to accelerate technological growth by introducing cyber-physical systems into industrial production and the industrial IoT. State Council of the People's Republic of China (2015), as part of the national digital development strategy "Internet Plus" (Internet Plus), published the "Made in China 2025" program, which is based on the integration of information and communication technologies and industrialization, as well as the application of in the artificial intelligence industry. Goal: transformation and modernization of key industries and meeting the basic needs for the development of new generations of information technology (smart manufacturing, production of additives, new materials and biomedicine).

In France, in 2013, the French industrial development plan "NewlndustrialFrance" was adopted, providing institutional support to 34 industrial projects, including "Fabric of the Future", "Robotics", "Supercomputers", etc. This document is coordinated with the strategic plan of scientific and technical research, diffusion of innovations, European technology transfer and brings together the interests of private business, the scientific community and the state. United Kingdom adopted the Strategic Industrial Development Plan until 2050 (United Kingdom Digital Strategy 2017), the first section of which sets strategic goals for the development of the digital economy and digital transformation of industry within the framework of the Industry 4.0 concept. At the same time, the Industry 4.0 concept was taken as a basis for the formation of national programs for the digital transformation of industry in many industrially developed European countries, such as: Austria, Belgium, Hungary, Denmark, Italy, Spain, Lithuania, Netherlands, Poland, Portugal, Slovakia, Czech Republic, Sweden, etc.

\section{REFERENCES}

1. Burenina, I. V., Gayfullina, M. M., Sayfullina, S. F. (2018). The social and economic transformations connected with implementation of projects of development and deployment of Industry 4.0 Technologies. The Eurasian Scientific Journal, vol. 5, no. 10.

2. Rojko, A. (2017). Industry 4.0 concept: background and overview. International Journal of Interactive Mobile Technologies, vol. 11, no. 5, 77-90.

3. Avdeeva, I. L., Polyanin, A. V., Golovina, T. A. (2019). Industrial Economic Systems' Digitalization: Problems and Consequences of Modern Technologies. Bulletin of the Saratov University. New episode. Series Economics. Management. Law, vol. 19, no. 3, 238-245.

4. Wiktorsson, M., Noh, S. D., Bellgran, M., Hanson, L. (2018). Smart Factories: South Korean and Swedish examples on manufacturing settings. Procedia Manufacturing, vol. 25, 471-478.

5. Shendrikova, O. O., Elfimova, I. F. (2019). The study of processes related to digitalization of industrial enterprises. Organizer of Production, vol. 27, no. 1, 16-24.

6. Schuh, G., Anderl, R., Gausemeier, J., Ten Hompel, M., Wahlster, W. (2017). Industrie 4.0 Maturity Index: Die digitale Transformation von Unternehmengestalten. Herbert Utz Verlag, München.

7. Shahrubudin, N., Chuan, L. T., Ramlan, R. (2019). An overview of critical success factors for implementing $3 \mathrm{~d}$ printing technology in manufacturing firms. Journal of Applied Engineering Science, vol. 17 , no. 3, 379-385.

8. Dovbiy, I. P., Ionova, N. V., Dovbiy, N. S. (2019). Fourth industrial revolution (aspects of investment and financial and personnel support). Bulletin of the South Ural State University. Series Economics and Management, vol. 13, no. 1, 120-131.

9. Hofmann, E., Rüsch, M. (2017). Industry 4.0 and the current status as well as future prospects on logistics. Computers in Industry, vol. 89, 23-34.

10. Sergeeva, O. Yu. (2018). "Industry 4.0" as a mechanism for formation of "Smart production". Nanotechnologies in Construction, vol. 10, no. 2, 100-113.

11. Novikov, S. V., Sazonov, A. A. (2020). Digital transformation of machine-building complex enterprises. Journal of Physics: Conference Series, vol. 1515, no. 3, 032021.

12. Saldivar, A. A. F., Li, Y., Chen, W. N., Zhan, Z. H., Zhang, J., Chen, L. Y. (2015). Industry 4.0 with cyber-physical integration: A design and manufacture perspective. Proceedings of 21st International Conference on Automation and Computing (ICAC) 2017, p. 260-265. 
13. Rakyta, M., Fusko, M., Hercko, J., Zavodska, L., Zavodska, N. (2016). Proactive approach to smart maintenance and logistics as a auxiliary and service processes in a company. Journal of Applied Engineering Science, vol. 14, no. 4, 433-442.

14. Zhou, K., Liu, T., Zhou, L. (2015). Industry 4.0: Towards future industrial opportunities and challenges. 12th International Conference on Fuzzy Systems and Knowledge Discovery 2015, p. 2147-2152.

15. Lima, R. M. (2010). Integrating production planning and control business processes. Information Resources Management: Concepts, Methodologies, Tools and Applications. IGI Global, Hershey, p. 391-412.

16. Kretzschmar, N., Chekurov, S., Salmi, M., Tuomi, J. (2018). Evaluating the Readiness Level of Additively Manufactured Digital Spare Parts: An Industrial Perspective. AppliedSciences, vol. 8, no. 10, 1837.

17. Agostini, L., Filippini, R. (2019). Organizational and managerial challenges in the path toward Industry 4.0. European Journal of Innovation Management, vol. 22, no. 3, 406-421.

18. Jovanović, M., Lalić, M., Mas, A., Mesquida, A. L. (2015). The agile approach in industrial and software engineering project management. Journal of Applied Engineering Science, vol. 13, no. 4, 213-216.

19. Yin, R. K. (2018). Case Study Research and Applications: Design and Methods, Sixth edition. SAGE Publications, Los Angeles.

20. Jesus, C. de, Lima, R. M. (2020). Literature Search of Key Factors for the Development of Generic and Specific Maturity Models for Industry 4.0. AppliedSciences, vol. 10, no. 17,5825 .
21. Mičieta, B., Herčko, J., Botka, M., Zrnić, N. (2016). Concept of intelligent logistic for automotive industry. Journal of Applied Engineering Science, vol. 14, no. 2, 233-238.

22. Pfeiffer, S. (2017). The vision of «Industrie 4.0» in the making - a case of future told, tamed, and traded. NanoEthics, vol. 11, no. 1, 107-121.

23. Samostroenko, G. M., Sulima, E. P. (2017). "Digital” Inheritance as a Factor of Development of Entrepreneurship in the Sphere of Protecting Personal Data. Central Russian Journal of Social Sciences, vol. 12, no. 1, 252-258.

24. Bauernhansl, T. (2014). Die Viertelndustrielle Revolution - Der Weg in einwertschaffendesProduktionsparadigma. In Industrie 4.0 in Produktion, Automatisierung und Logistik, T. Bauernhansl, M. ten Hompel, und B. Vogel-Heuser, Hrsg. Springer Fachmedien Wiesbaden, Wiesbaden.

25. Dmitriev, O. N., Novikov, S. V. (2019). Verification of Feasibility Studies at High-Technology. Russian Engineering Research, vol. 39, no. 9, 780-781.

26. Kosareva, I. N., Samarina, V. P. (2019). The management features of the enterprises in the conditions of digitalization. The Eurasian Scientific Journal, vol. 3, no. 11 . 